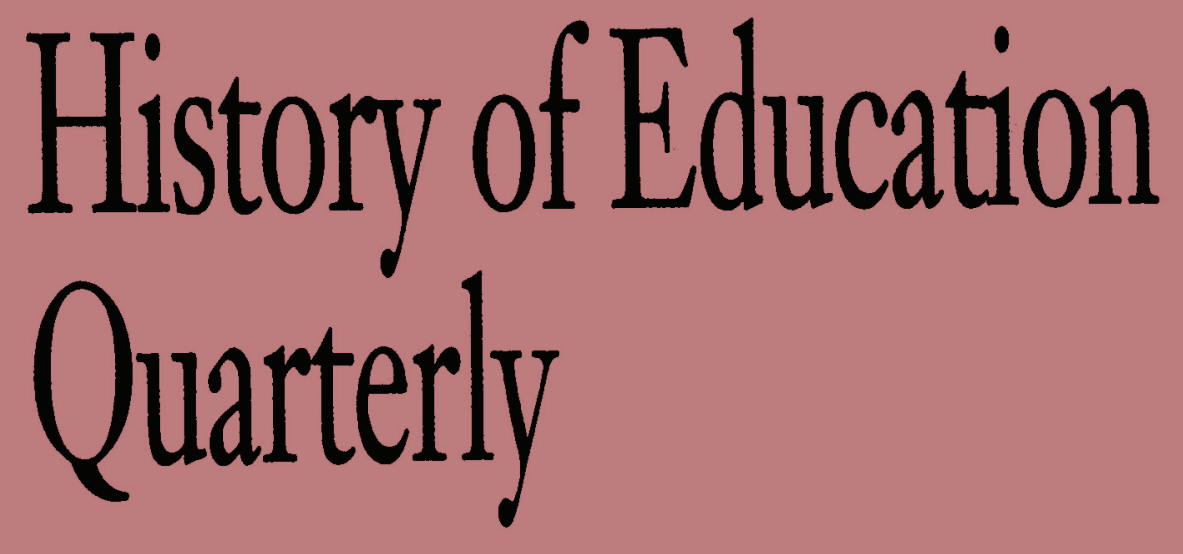

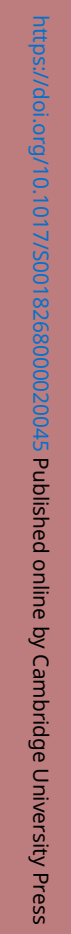

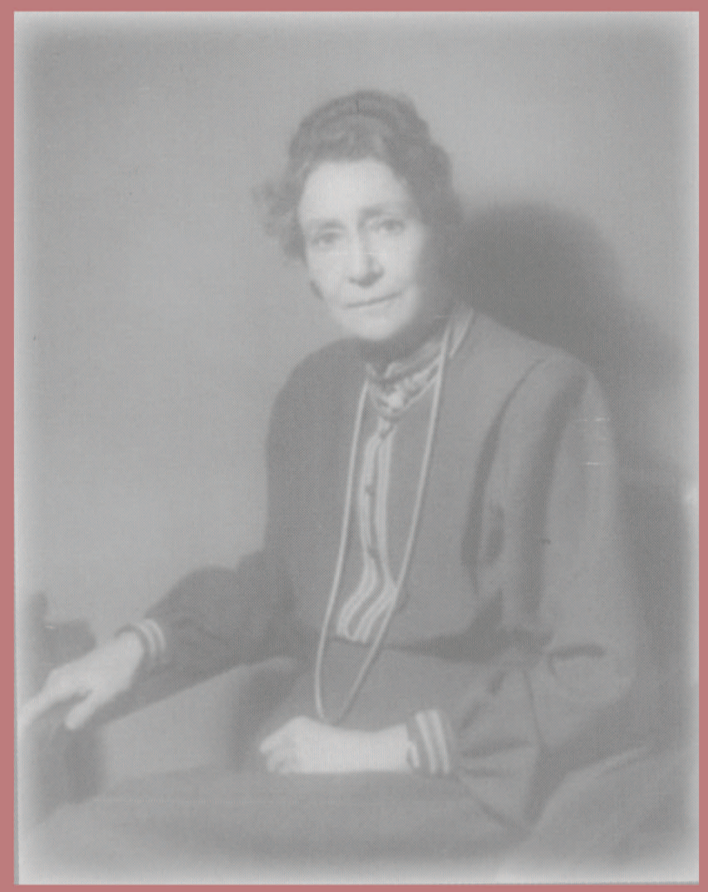

November 2009

Volume 49, Number 4 
THE CLAUDE A. EGGERTSEN DISSERTATION PRIZE: The History of Education Society is accepting submissions for the Claude A. Eggertsen Prize for the dissertation judged to be the most outstanding in the field of History of Education. The prize carries an award of $\$ 1,000$ for the winner. 2009 Committee members: Sevan Terzian (Chair), Maggie Nash.

2008 winner: Zoe Burkholder, “With Science as His Shield': Teaching Race and Culture in American Public Schools, 1900-1954." New York University.

Eggertsen Dissertation Award Committee for 2009:

Chair, Sevan Terzian, (2006-2009) University of Florida

Maggie Nash, (2007-2010) University of California, Riverside

Val Littlefield, (2008-2011) University of South Carolina

THE HISTORY OF EDUCATION BEST ARTICLE AWARD: The History of Education Society awards a prize of $\$ 500$ biennially (in alternating years with the Henry Barnard Prize) for the best article in the history of education, broadly defined to cover a wide range of educational and cultural institutions inside and outside of the United States. This includes work on schools and universities, teachers, students, and families. The next award will be presented at the fall 2010 meeting of the History of Education Society. Articles published in journals during 2008 and 2009 (no book chapters) will be eligible. Self-nominations are also welcome. The postmark date for entries is April 1, 2010.

Best Article Winner for 2008: Kim Tolley, Notre Dame de Namur University, and Nancy Beadie, University of Washington. "Socioeconomic Incentives to Teach in New York and North Carolina: Toward a More Complex Model of Teacher Labor Markets, 1800-1850."

Honorable Mention: Jennifer de Forest, University of Virginia. "Conservatism Goes to College: The Role of Philanthropic Foundations in the Rise of Conservative Student Networks."

Honorable Mention: Ronald E. Butchart, University of Georgia. "Remapping Racial Boundaries: Teachers as Border Police and Boundary Transgressors in Post-Emancipation Black Education, USA, 1861-1876."

THE HENRY BARNARD PRIZE: The History of Education Society awards the Henry Barnard Prize of $\$ 500$ biennially (in alternating years with the Best Article Prize) for the best graduate student essay in the history of education. Nominations by faculty, graduate advisers, department chairs, and deans, as well as self-nominations by students, are welcome. HES also extends a $\$ 250$ travel supplement to the Barnard Prize winner for his/her attendance at the annual meeting, and covers the costs of registration and the banquet. 2009 Committee Members: Chris Ogren (Chair), Benita Blessing, Milton Gaither, Adah Ward Randolph, Christine Woyshner.

2007 Winner: Paul J. Ramsey, Indiana University. "In the Region of Babel: Public Bilingual Schooling in the Midwest, 1840s-1880s."

2007 Honorable Mention: Katherine Sedgwick, University of Pennsylvania. "From Hazing to Socialization: A History of Social Conformity and Freshman Orientation."

Barnard Prize Committee for 2009 (alternating years with Best Article Award):

Chair, Christine Ogren, (2006-2009) University of Iowa

Adah Ward Randoph, (2006-2009) Ohio University

Christine Woyshner, (2006-2009) Temple University

Benita Blessing, (2007-2010) Ohio University

OUTSTANDING BOOK AWARD: The History of Education Society sponsors an Outstanding Book Award. This award of $\$ 1,000$ is made annually to the author of the best book published in the preceding year. 2008 Committee members: Richard Angelo (Chair), Bethany Rogers, and Amy McCandless

2008 Award Winners

Outstanding Book Award Winner for 2008: Adam Fairclough, Leiden University, A Class of Their Own: Black Teachers in the Segregated South (Harvard University Press, 2007).

Outstanding Book Award Committee for 2009:

Chair, Bethany Rogers, (2006-2009) College of Staten Island

Amy McCandless, (2007-2010) College of Charleston

John Rudolph, (2008-2011) University of Wisconsin-Madison 
History of Education Quarterly

University of Illinois at Urbana-Champaign

360 Education Building, MC-708

1310 South Sixth Street, Champaign, IL 61820

Phone: 217 333-2446 (Office), Fax: 217 244-7064

http://www.ed.uiuc.edu/hes/INDEX.htm

Senior Editor

James D. Anderson, University of Illinois at Urbana-Champaign

Co-Editors

Yoon K. Pak,

Unizersity of Illinois at Urbana-Champaign

Book Review Editor

Katrina M. Sanders, University of Iowa

Associate Editors

David Adams, Cleveland State University

Nancy Beadie, University of Washington, Seattle

Kate Rousmaniere, Miami University

Eileen Tamura, University of Hawaii

Timothy Cain, University of Illinois at Urbana-Champaign Wayne Urban, University of Alabama

Paul W. Mathewson

Editorial Assistants

Mario Rios Perez

Kevin Zayed

\section{Book Review Editorial Assistants}

DeeAnn Grove, Unizersity of Iowa

Michael Hevel, University of Iowa

\section{Editorial Board}

\section{TERM EXPIRES IN 2010}

Carlos Blanton, Texas A\&M University

Benita Blessing, Obio University

James W. Fraser, New York University

Marybeth Gasman, University of Pennsylvania

Karen Graves, Denison University

$\mathrm{K}$. Tsianina Lomawaima, University of Arizona

Jeffrey Mirel, University of Michigan

Kathleen Weiler, Tufts University

Joy Williamson-Lott, University of Washington, Seattle

Robert S. Wolff, Central Connecticut State University

Roberta Wollons, University of Massachusetts, Boston

\section{TERM EXPIRES IN 2009}

Mona Gleason, University of British Columbia

Joyce Goodman, University of Winchester

Philo Hutcheson, Georgia State University

W. Bruce Leslie, State University of New York, Brockport

Gary McCulloch, University of London

Adah Ward Randolph, Obio University

Alan Sadovnik, Rutgers Unversity

Joseph Watras, University of Dayton

The History of Education Society is an international scholarly society. Its purposes are to encourage and facilitate research in the history of education; to promote and improve the teaching of history of education; to encourage cooperation among specialists in history of education; and to promote an appreciation of the value of historical perspective in the making of educational policy. The Society is affiliated with the International Standing Conference for the History of Education, and members of the Society are automatically members of the Standing Conference.

$\begin{array}{ccc}\text { President } & \text { Vice-President } & \text { Secretary-Treasurer } \\ \text { Eileen Tamura, University of } & \text { Jonathan Zimmerman, New York } & \text { Robert Hampel, University of } \\ \text { Hawaii (2009) } & \text { University (2009) } & \text { Delaware (2009) }\end{array}$

Harold Wechsler, New York University (2009)

Andrea Walton, Indiana University (2007-2009)

\section{Directors}

Kim Tolley, Notre Dame de Namur University (2008-2010)

INDIVIDUAL MEMBERSHIP: Membership is open to all persons interested in the study of the history of education. Membership provides for subscription to the History of Education Quarterly; subscription to The Network, a newsletter published jointly with Division $\mathrm{F}$ of the American Educational Research Association; and receipt of the program of the annual meeting of the Society. Members of the Society are automatically members of the International Standing Conference for the History of Education. Membership offers subscription to publications on a calendar-year basis only. Dues are $\$ 25$ for students, $\$ 50$ for others. NonU.S. members should add \$7 to cover additional postage for surface mail; $\$ 20$ for airmail. To become a member, send a check for the appropriate amount in U.S. dollars only to Journal Customer Services, John Wiley \& Sons, 350 Main Street, Malden, MA 02148 , USA, or to pay by credit card visit www.blackwellpublishing.com/journals/hoeq/members.htm

Make checks payable to John Wiley \& Sons. Indicate preferred mailing address and the calendar year in which your subscription should begin. 


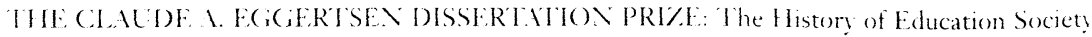
is accepting submissions for the Claude A. Eggertsen Prize for the dissertation judged to be the most outstanding in the field of History of Education. The prize carries an award of $\$ 1,000$ for the winner. 2009 Committee members: Sevan Terzian (Chair), Maggie Nash.

2008 winner: Zoe Burkholder, "With Science as His Shield': Teaching Race and Culture in American Public Schools, 1900-1954." New York University:

Eggertsen Dissertation Award Committee for 2009:

Chair, Sevan Terzian, (2006-2009) University of Florida

Maggie Nash, (2007-2010) University of California, Riverside

Val Littlefield, (2008-2011) University of South Carolina

THE HISTORY OF EDUCATION BEST ARTICLE AWARD: The History of Education Society awards a prize of $\$ 500$ biennially (in alternating years with the Henry Barnard Prize) for the best article in the history of education, broadly defined to cover a wide range of educational and cultural institutions inside and outside of the United States. This includes work on schools and universities, teachers, students, and families. The next award will be presented at the fall 2010 meeting of the History of Education Society. Articles published in journals during 2008 and 2009 (no book chapters) will be eligible. Self-nominations are also welcome. The postmark date for entries is April 1, 2010.

Best Article Winner for 2008: Kim Tolley, Notre Dame de Namur Lniversity, and Nancy Beadie. University of Washington. "Socioeconomic Incentives to Teach in New York and North Carolina: Toward a More Complex Model of Teacher Labor Markets, 1800-1850."

Honorable Mention: Jennifer de Forest, University of Virginia. "Conservatism Goes to College: The Role of Philanthropic Foundations in the Rise of Conservative Student Networks."

Honorable Mention: Ronald E. Butchart, University of Georgia. "Remapping Racial Boundaries: Teachers as Border Police and Boundary Transgressors in Post-Emancipation Black Education, USA, 1861-1876."

THE HENRY BARNARD PRIZE: The History of Education Society awards the Henry Barnard Prize of $\$ 500$ biennially (in alternating years with the Best Article Prize) for the best graduate student essay in the history of education. Nominations by faculty, graduate advisers, department chairs, and deans, as well as self-nominations by students, are welcome. HES also extends a \$250 travel supplement to the Barnard Prize winner for his/her attendance at the annual meeting, and covers the costs of registration and the banquet. 2009 Committee Members: Chris Ogren (Chair), Benita Blessing, Milton Gaither, Adah Ward Randolph, Christine Woyshner.

2007 Winner: Paul J. Ramsey, Indiana University. "In the Region of Babel: Public Bilingual Schooling in the Midwest, 1840s-1880s."

2007 Honorable Mention: Katherine Sedgwick, University of Pennsylvania. "From Hazing to Socialization: A History of Social Conformity and Freshman Orientation."

Barnard Prize Committee for 2009 (alternating years with Best Article Award):

Chair, Christine Ogren, (2006-2009) University of Iowa

Adah Ward Randoph, (2006-2009) Ohio University

Christine Woyshner, (2006-2009) Temple University

Benita Blessing, (2007-2010) Ohio University

OUTSTANDING BOOK AWARD: The History of Education Society sponsors an Outstanding Book Award. This award of $\$ 1,000$ is made annually to the author of the best book published in the preceding year. 2008 Committee members: Richard Angelo (Chair), Bethany Rogers, and Amy McCandless

\section{Award Winners}

Outstanding Book Award Winner for 2008: Adam Fairclough, Leiden University, A Class of Their Own: Black Teachers in the Segregated South (Harvard University Press, 2007).

Outstanding Book Award Committee for 2009:

Chair, Bethany Rogers, (2006-2009) College of Staten Island

Amy McCandless, (2007-2010) College of Charleston

John Rudolph, (2008-2011) University of Wisconsin-Madison 
History of Education Quarterly

University of Illinois at Urbana-Champaign

360 Education Building, MC-708

1310 South Sixth Street, Champaign, IL 61820

Phone: 217 333-2446 (Office), Fax: 217 244-7064

http://www.ed.uiuc.edu/hes/INDEX.htm

Senior Editor

James D. Anderson, University of Illinois at Urbana-Champaign

Co-Editors

Yoon K. Pak,

Unizersity of Illinois at Urbana-Champaign
Book Review Editor

Katrina M. Sanders, University of Iowa

Associate Editors

David Adams, Cleveland State University

Nancy Beadie, University of Wasbington, Seattle

Kate Rousmaniere, Miami University

Eileen Tamura, University of Hawaii

Timothy Cain, University of Illimois at Urbana-Champaign Wayne Urban, University of Alabama

Paul W. Mathewson

Editorial Assistants

Mario Rios Perez

Kevin Zayed
DeeAnn Grove, University of Iowa

\section{TERM EXPIRES IN 2010}

Carlos Blanton, Texas A\&M University

Benita Blessing, Obio University

James W. Fraser, New York University

Marybeth Gasman, University of Pennsylvania

Karen Graves, Denison University

K. Tsianina Lomawaima, University of Arizona

Jeffrey Mirel, University of Michigan

Kathleen Weiler, Tufts University

Joy Williamson-Lott, University of Washington, Seattle

Robert S. Wolff, Central Connecticut State University

Roberta Wollons, University of Massachusetts, Boston

\section{Editorial Board}

TERM EXPIRES IN 2009

Mona Gleason, University of British Columbia

Joyce Goodman, University of Winchester

Philo Hutcheson, Georgia State University

W. Bruce Leslie, State University of New York, Brockport

Gary McCulloch, University of London

Adah Ward Randolph, Obio University

Alan Sadovnik, Rutgers Unversity

Joseph Watras, University of Dayton

The History of Education Society is an international scholarly society. Its purposes are to encourage and facilitate research in the history of education; to promote and improve the teaching of history of education; to encourage cooperation among specialists in history of education; and to promote an appreciation of the value of historical perspective in the making of educational policy. The Society is affiliated with the International Standing Conference for the History of Education, and members of the Society are automatically members of the Standing Conference.

\section{President}

Eileen Tamura, University of Hawaii (2009)
Vice-President

Jonathan Zimmerman, New York

University (2009)
Secretary-Treasurer

Robert Hampel, University of

Delaware (2009)
Harold Wechsler, New York University (2009)

Andrea Walton, Indiana University (2007-2009)

\section{Directors}

Kim Tolley, Notre Dame de Namur University (2008-2010)

INDIVIDUAL MEMBERSHIP: Membership is open to all persons interested in the study of the history of education. Membership provides for subscription to the History of Education Quarterly; subscription to The Network, a newsletter published jointly with Division F of the American Educational Research Association; and receipt of the program of the annual meeting of the Society. Members of the Society are automatically members of the International Standing Conference for the History of Education. Membership offers subscription to publications on a calendar-year basis only. Dues are $\$ 25$ for students, $\$ 50$ for others. NonU.S. members should add $\$ 7$ to cover additional postage for surface mail; $\$ 20$ for airmail. To become a member, send a check for the appropriate amount in U.S. dollars only to Journal Customer Services, John Wiley \& Sons, 350 Main Street, Malden, MA 02148, USA, or to pay by credit card visit www.blackwellpublishing.com/journals/hoeq/members.htm

Make checks payable to John Wiley \& Sons. Indicate preferred mailing address and the calendar year in which your subscription should begin. 
Article Submissions: Manuscripts must be submitted electronically to the History of Education Quarterly manuscript submission site, http://ojs.ed.uiuc.edu/index.php/heq/index. Questions regarding submissions can be directed to the editorial staff at heq@ed.uiuc.edu. See last page of this issue or our website www.blackwellpublishing.com/HOEQ for guidelines on submission. The editor will only consider articles that have been submitted exclusively to the History of Education Quarterly.

Book Reviews: Assignments of reviews are made from a file of potential reviewers. To have your name added to that file, send curriculum vitae to the book review editor. Requests to review particular books cannot be honored.

HISTORY OF EDUCATION QUARTERLY, (Print ISSN: 0018-2680 Online ISSN: 1748-5959), is published quarterly on behalf of the History of Education Society in conjunction with the College of Education, the University of Illinois a Urbana-Champaign, 360 Education Building, MC-708, 1310 South Sixth St., Champaign, IL 61820 by Wiley Subscription Services, Inc., a Wiley Company, 111 River St., Hoboken, NJ 07030-5774.

Mailing: Periodical Postage Paid at Hoboken, NJ and additional offices.

Postmaster: Send all address changes to HISTORY OF EDUCATION QUARTERLY, Journal Customer Services, John Wiley \& Sons, Inc., 350 Main St., Malden, MA 02148-5020.

Publisher

History of Education Quarterly is published by Wiley Periodicals, Inc., Commerce Place, 350 Main Street, Malden, MA 02148; Telephone: 781388 8200; Fax: 7813888210

Journal Customer Services: For ordering information, claims and any enquiry concerning your journal subscription please go to interscience.wiley.com/support or contact your nearest office:

Americas: Email cs-journals@wiley.com; Tel: +1 7813888598 or 18008356770 (Toll free in the USA \& Canada).

Europe, Middle East and Africa: Email: cs-journals@wiley.com; Tel: +44(0) 1865778315

Asia Pacific: Email: cs-journals@wiley.com; Tel: +65 65118000

Production Editor: James Lui (email: HOEQ@bos.blackwellpublishing.com)

Information for Subscribers

History of Education Quarterly is published in 4 issues per year. Subscription prices for 2009 are: Institutional Print \& Online Rate: US\$132 (the Americas), US\$167 (Rest of World), €108 (Europe), £85 (UK). Prices are exclusive of tax. AsiaPacific GST, Canadian GST and European VAT will be applied at the appropriate rates. For more information on current tax rates, please go to www3.interscience.wiley.com/aboutus/journal_ordering_and_payment.huml\#Tax. The Institutional Print \& Online price includes online access to the current and all online back files to January 1, 1997, where available. For other pricing options, including access information and terms and conditions, please visit www.interscience.wilev: com/journals.

\section{Delivery Terms and Legal Title}

Prices include delivery of print journals to the recipient's address. Delivery terms are Delivered Duty Unpaid (DDU); the recipient is responsible for paying any import duty or taxes. Legal title passes to the customer on despatch by our distributors.

Back Issues: Single issues from current and recent volumes are available at the current single issue price from cs-journals@wiley.com. Earlier issues may be obtained from the Periodicals Service Company, 11 Main Street, Germantown, NY 12526, USA. Tel: +1 518537 4700, Fax: +1 518537 5899, Email: psc@periodicals.com.

\section{Copyright and Photocopying}

0 2009 History of Education Society. All rights reserved. No part of this publication may be reproduced, stored or transmitted in any form or by any means without the prior permission in writing from the copyright holder. Authorization to photocopy items for internal and personal use is granted by the copyright holder for libraries and other users registered with their local Reproduction Rights Organisation (RRO), e.g. Copyright Clearance Center (CCC), 222 Rosewood Drive, Danvers, MA 01923, USA (www.copyright.com), provided the appropriate fee is paid directly to the RRO. This consent does not extend to other kinds of copying such as copying for general distribution, for advertising or promotional purposes, for creating new collective works or for resale. Special requests should be addressed to: PermissionsUK@wiley.com.

Advertising: For advertising enquiries, please email Kristin McCarthy (email: kmccarthy@wiley.com)

\section{Disclaimer}

The Publisher, History of Education Society, and Editors cannot be held responsible for errors or any consequences arising from the use of information contained in this journal; the views and opinions expressed do not necessarily reflect those of the Publisher, History of Education Society, and Editors, neither does the publication of advertisements constitute any endorsement by the Publisher, History of Education Society, and Editors of the products advertised.

This journal is available online at Wiley InterScience. Visit www 3 .interscience.wiley.com to search the articles and register for table of contents email alerts.

For submission instructions, subscription and all other information visit: www.blackwellpublishing.com/HOEQ.

ISSN 0018-2680 (Print)

ISSN 1748-5959 (Online)

Printed in the USA by The Sheridan Press. 


\section{History \\ of Education \\ Quarterly}

Volume 49 • Number 4 • November 2009

\section{Contents}

\section{Articles}

417 Contested Identities: Nationalism, Regionalism, and Patriotism in Early American Textbooks

Margaret A. Nash

442 Transitory Connections: The Reception and Rejection of Jean Piaget's Psychology in the Nursery School Movement in the 1920s and 1930s

Barbara Beatty

465 A Maverick in the Field: The Oram Group and Fundraising in the Black College Community during the 1970s

Marybeth Gasman and Noab D. Drezner

$507 \quad$ Unequal Pieces of a Shrinking Pie: The Struggle between African Americans and Latinos over Education, Employment, and Empowerment in Compton, California

Emily E. Straus

\section{Book Reviews}

$530 \quad$ Haney, The Americanization of Social Science: Intellectuals and Public Responsibility in the Postwar United States

By Chara Haeussler Boban

534 Weber, Our Friend "The Enemy": Elite Education in Britain and Germany before World War I

By fim Carl 
$543 \quad$ Krause, Nolan, Palm, and Ross, eds., The University Against Itself: The NYU Strike and the Future of the Academic Workplace By Christina Collins

$548 \quad$ Cortina and San Román, eds., Women and Teaching: Global Perspectives on the Feminization of a Profession By Diana D'Amico

553 Van Cleve, ed., The Deaf History Reader and Lane, ed., and Philip, translator, The Deaf Experience: Classics in Language and Education

By R.A.R. Edwards

556 Dierenfield, The Battle over School Prayer: How Engel v. Vitale Changed America

By James W. Fraser

$559 \quad$ Knupfer and Woyshner, eds., The Educational Work of Women's Organizations, 1890-1960

By Karen L. Graves

562 Anderson, Congress and the Classroom: From the Cold War to "No Child Left Bebind"

By DeeAnn Grove

566 McBride with McLaurin, Randall Lee Gibson of Louisiana: Confederate General and New South Reformer By Phillip 7. Jobnson

568 Szasz, Scottish Highlanders and Native Americans: Indigenous Education in the Eigbteentb-Century Atlantic World By K. Tsianina Lomawaima

572 Miller, Piety and Profession: American Protestant Theological Education, 1870-1970

By Bradley 7. Longfield

576 Johnson, Southern Women at the Seven Sister Colleges: Feminist Values and Social Activism, 1875-1915

By Paul Marthers 
Mettler, Soldiers to Citizens: The G.I. Bill and the Making of the Greatest Generation

By Deanna L. Michael

584 DeLuzio, Female Adolescence in American Scientific Thought, 1830-1930

By Kim Tolley

PHOTO CREDIT: Lucy Sprague Mitchell, circa 1951. Bank Street College Archives, Record Group 2, Office of the President, 1916-1999. 